\title{
A non-essential glutamyl aminopeptidase is required for optimal growth of Lactococcus lactis MG1363 in milk
}

\author{
K. J. A. I'Anson, ${ }^{1}$ S. Movahedi, ${ }^{3}$ H. G. Griffin, ${ }^{1}$ M. J. Gasson ${ }^{1}$ \\ and F. Mulholland ${ }^{2}$
}

Author for correspondence: K. I'Anson. Tel: +44 1603 255000. Fax: +441603 507723.

\footnotetext{
1 Institute of Food Research, Norwich Laboratory, Norwich Research Park, Colney, Norwich NR4 7UA UK

2 Institute of Food Research, Reading Laboratory, Earley Gate, Whiteknights Road, Reading RG6 6BZ, UK

3 Biochemistry and Molecular Biology Department, Leeds University, Leeds LS2 9JT, UK
}

\begin{abstract}
Degenerate PCR primers were designed from the $\mathbf{N}$-terminal amino acid sequence of a glutamyl aminopeptidase (PepA) from Lactococcus lactis. These primers were used to screen a lambda library for clones containing the gene (pepA) encoding PepA. The DNA sequence of a $2.1 \mathrm{~kb}$ fragment containing pepA was determined. The sequence revealed the presence of one complete and two incomplete open reading frames (ORFs). The complete ORF encodes a putative protein of 353 amino acids with a predicted $\mathbf{N}$-terminal sequence identical to that determined for purified PepA. The pepA gene was subcloned on an Escherichia coll plasmid vector and production of active PepA was confirmed by means of a zymogram. Mutants of $L$. lactis in which the pepA gene was inactivated grew to normal cell densities in milk but exhibited a reduced growth rate during the exponential phase. Thus whilst PepA is required for optimal growth it is not essential.
\end{abstract}

Keywords: aminopeptidase, PCR screening, Lactococcus lactis subsp. lactis, nucleotide sequence analysis

\section{INTRODUCTION}

The growth of lactic acid bacteria (LAB) in milk is limited by the initial concentration of free amino acids and small peptides. For rapid multiplication, LAB rely on their ability to break down the milk protein, casein, to provide essential amino acids for cell protein synthesis. As a consequence of this, LAB have a specialized proteolytic system to allow the efficient degradation and utilization of casein. The proteolytic system consists of a membranebound proteinase (Laan et al., 1989) which has been extensively studied (for reviews see Kok, 1990; Visser, 1993; Pritchard \& Coolbear, 1993); transport systems to allow uptake of the resultant amino acids and peptides (Poolman, 1993; Hagting et al., 1994; Kunji et al., 1995); and several intracellular peptidases for further degradation of the generated peptides. In an attempt to fully understand this system, several of the peptidase genes of Lactococcus lactis have been isolated, cloned and sequenced (Mayo et al., 1991; Strøman, 1992; Chapot-Chartier et al.,

Abbreviations: LAB, lactic acid bacteria; PepA, glutamyl aminopeptidase; $P N A, p$-nitroanilide.

The EMBL accession number for the sequence reported in this paper is X81089.
1993; Mierau et al., 1993b, 1994; van Alen-Boerrigter et al., 1991; Monnet et al., 1994).

Glutamic acid is one of the essential amino acids required by $L$. lactis in order to sustain growth (Mills \& Thomas, 1981). Its concentration in milk is below the minimum required for cell protein synthesis (Thomas \& Mills, 1981) and the involvement of the LAB proteolytic system is necessary to provide this essential nutrient from the milk proteins. LAB peptidases capable of releasing glutamate from milk proteins and peptides are of potential significance in this process.

Glutamate is an important flavour-enhancing component in many foods. It is also one of the most prevalent amino acids in cheese, and cheese flavour development coincides with the increasing content of glutamic acid during ripening (Puchades et al., 1989). The peptidases of LAB are considered to play an important role in cheese ripening processes (Law, 1987). Of these peptidases, glutamyl aminopeptidase (PepA), which has activity against $\mathrm{N}$ terminal aspartyl- and glutamyl-containing peptides (Exterkate \& de Veer, 1987; Niven, 1991), is potentially involved both in the release of glutamate for growth of LAB in milk, and in the accumulation of glutamate in cheese. 
In this paper we describe the cloning and sequencing of the pep $A$ gene, encoding PepA, from $L$. lactis subsp. cremoris MG1363 (Gasson, 1983) and its expression in Escherichia coli. To investigate the role of PepA in intracellular proteolysis we constructed $\operatorname{pep} A$ mutants and examined their ability to grow on milk.

\section{METHODS}

Bacterial strains, plasmids and growth conditions. Escherichia coli MC1022 (Casadaban \& Cohen, 1980) was used as recipient in molecular cloning. E. coli LE392 (Sambrook et al., 1989) was used to propagate lambda phage. E. coli was grown in LuriaBertani (LB) medium (Sambrook et al., 1989) at $37^{\circ} \mathrm{C}$. When appropriate, ampicillin was added to a concentration of $200 \mathrm{mg} \mathrm{ml}^{-1}$. The vector pUC18 (Yanisch-Perron et al., 1985) was from Pharmacia. Plasmid pFI872 is pUC18 containing a $4.2 \mathrm{~kb} E c o \mathrm{RI}$ insert from $L$. lactis carrying the pep $A$ gene. FI7894 is MC1022 containing pFI872. Plasmid pFI950 is pCRII (Invitrogen Corporation) with a $0.76 \mathrm{~kb}$ PCR product (truncated $p e p A$ gene) and erythromycin resistance gene cloned into the multiple cloning site. The $L$. lactis strains used were MG1363 (Gasson, 1983), FI5876 (Dodd et al., 1990) and MG4695 (MG1363 with the pLP712: Gasson, 1983). L. lactis strains FI8362, FI8364 and FI8365 are pep $A$ mutants with the pFI950 integrated into the chromosome. L. lactis was grown in M17 (Terzaghi \& Sandine, 1975) supplemented with $0.5 \%$ (w/v) glucose or lactose and when appropriate with erythromycin $\left(5 \mu \mathrm{g} \mathrm{ml}^{-1}\right)$ at $30^{\circ} \mathrm{C}$ without agitation. Growth analysis of $p e p A$ mutants was carried out in $10 \%$ (w/v) low-lowtemperature reconstituted skimmed milk (kindly supplied by $\mathrm{G}$. Fitzgerald, University of Cork) steamed for $15 \mathrm{~min}$ on two successive days.

Growth analysis of pepA mutants. The $\mathrm{OD}_{600}$ of exponentially growing cultures (in broth) was determined and cultures diluted with broth to give the same optical density in each culture. Ten microlitres of the diluted culture was used to inoculate $10 \mathrm{ml}$ $10 \%$ reconstituted skimmed milk and incubation performed at $30{ }^{\circ} \mathrm{C}$. Samples were taken at hourly intervals. The $\mathrm{pH}$ was measured and the $\mathrm{OD}_{600}$ determined using a Uvikon 860 spectrophotometer (Kontron Instruments) by the method of Kanasaki et al. (1975): $100 \mu \mathrm{l}$ milk culture was mixed with $900 \mu \mathrm{l}$ $0.5 \mathrm{M}$ sodium borate ( $\mathrm{pH} 8{ }^{\circ}$ ) containing $30 \mathrm{mM}$ EDTA. The actual values of $\mathrm{OD}_{600}$ and $\mathrm{pH}$ for each time point were calculated as the mean of three individual readings from three separate cultures (i.e. nine separate readings) for each strain. These experiments were repeated several times to confirm that readings were accurate. Statistical significance of the results was determined by Student's $t$-test.

DNA manipulations. Transformation of, and plasmid isolation from, E. coli were carried out as described by Sambrook et al. (1989). Chromosomal DNA was isolated from $L$. lactis by the method of Lewington et al. (1987). Lambda DNA was isolated using a Qiagen lambda DNA kit (Diagen) according to the manufacturer's instructions. Restriction endonucleases and T4 ligase were purchased from Gibco-BRL (Life Technologies) and used as recommended by the supplier. PCR products were cloned in PCRII (Invitrogen Corporation) following the manufacturer's instructions for use of the TA cloning kit. Transformation of $L$. lactis was performed by electroporation as described by Holo \& Nes (1989). Southern hybridizations were performed using an ECL direct labelling and detection kit (Amersham) according to the manufacturer's instructions.

Determination of $\mathbf{N}$-terminal sequence. PepA was purified according to the procedure of Niven (1991). The resulting purified enzyme was blotted onto polyvinylidene difluoride membranes (Problott, Applied Biosystems) as described by Gooderham (1984). The blotted protein was visualized by staining with Coomassie Blue G-250 and the bands excised. Nterminal protein sequencing was performed on these bands, placed directly into the sequencer reaction cartridge, using a $470 \mathrm{~A}$ gas-phase protein sequencer equipped with a $120 \mathrm{~A}$ on-line phenylthiohydantoin analyser (Applied Biosytstems), according to the procedure of Hunkapillar et al. (1983).

Primers used for library screening. Based on the codon usage in L. lactis (van de Guchte et al., 1992), pools of degenerate primers were designed from the $\mathrm{N}$-terminal sequence of PepA. Primer 1C (designed from the first 11 residues of the N-terminal sequence) consisted of a pool of 256 oligonucleotides with the sequence $5^{\prime}$-ATGGAA(T/C)TA'T'T'TGAT(G/A)A(A/T)$\mathrm{GT}(\mathrm{A} / \mathrm{T})(\mathrm{G} / \mathrm{A})(\mathrm{T} / \mathrm{A}) \mathrm{TGC}(\mathrm{A} / \mathrm{T})(\mathrm{T} / \mathrm{C}) \mathrm{TAAC}$; primer $5 \mathrm{C}$ (designed from the last 10 residues of the $\mathrm{N}$-terminal sequence) was a pool of 128 oligonucleotides with the sequence $5^{\prime}$ ATC(A/T)AC(A/T)AC(A/T)GG(A/T)CGTTCAAA(A/T)$\mathrm{CC}(\mathrm{A} / \mathrm{T}) \mathrm{GT}(\mathrm{A} / \mathrm{T}) \mathrm{GT}$. These primers generated a product of about 75 bp from lactococcal chromosomal DNA.

Construction of the lambda-ZAP library. The lambda-ZAP library was custom-made by Stratagene using L. lactis FI5876 (Dodd et al., 1990) genomic DNA.

Direct PCR screening of the lambda-ZAP library. Screening was carried out by a modification of the method of Griffin $e t$ al. (1993). The lambda-ZAP library was plated out onto ten plates to give a plaque density of about 200 p.f.u. per plate (Sambrook et al., 1989). A plaque lift was performed on each plate using nylon membranes (Amersham). Each filter was placed plaque side up in a sterile Petri dish and washed in $2 \mathrm{ml} \mathrm{SM}$ buffer (Sambrook et al., 1989). A $10 \mu \mathrm{l}$ aliquot was taken from each sample for analysis by PCR with primers $1 \mathrm{C}$ and $5 \mathrm{C}$. The products were analysed by PAGE. If a plate contained one or more phage plaques that had the target sequence, a band of approximately $75 \mathrm{bp}$ could be seen in the gel. In this way plates containing positive plaques were identified. A further plaque lift was carried out from each positive plate and the filter divided into ten segments (with the position of each segment marked on the positive plate). Each filter segment was placed in a $1.5 \mathrm{ml}$ Eppendorf tube containing $200 \mu \mathrm{l}$ SM buffer, vortexed, and $10 \mu$ aliquots were subjected to PCR with primers $1 \mathrm{C}$ and $5 \mathrm{C}$. In this way, separate positive segments were identified. The individual plaques (10-20 per segment) from those segments were 'picked' using a sterile glass Pasteur pipette into $200 \mu \mathrm{l} \mathrm{SM}$ buffer. Again $10 \mu \mathrm{l}$ aliquots were analysed by PCR with primers $1 \mathrm{C}$ and $5 \mathrm{C}$ and any positive plaques were plaque-purified (Sambrook et al., 1989).

Isolation of lambda DNA and subcloning of the lactococcal fragment. DNA was isolated from the plaque-purified positive plaque using a Qiagen Lambda isolation kit (Diagen). The lambda DNA was digested with EcoRI (lactococcal fragments were introduced into the lambda-ZAP library on EcoRI fragments). A 4.2 kb EcoRI fragment was cloned into pUC18 and plasmids containing the appropriate fragment were identified by performing PCR on the white colonies (Gussow \& Clackson, 1989).

DNA sequence analysis. Sequencing reactions were carried out using the Applied Biosystems 'Prism' ready reaction DyeDeoxy terminator cycle sequencing kit and an Applied Biosystems $373 \mathrm{~A}$ DNA sequencer according to the manufacturer's directions. Part of the $4 \cdot 2 \mathrm{~kb}$ chromosomal insert of $\mathrm{pFI} 872$ was sequenced using Universal and Reverse primers. Following this, synthetic primers were designed from the deduced sequence and synthesized (Applied Biosystems model 394). 
These were then used to sequence both strands of the DNA insert.

The Wisconsin Genetics Computer Group sequence analysis software package, version 7 (University of Wisconsin Biotechnology Center, Madison) was used to perform sequence comparisons, analysis of non-coding regions and to deduce protein sequences. Analysis of the DNA coding regions was done using the DNA strider program (Marck, 1988) on an Apple Macintosh LCIII computer.

Preparation of cell extracts. Overnight cultures $(500 \mathrm{ml})$ of either $E$. coli or $L$. lactis were pelleted by centrifugation and washed with $50 \mathrm{mM}$ Tris $/ \mathrm{HCl} \mathrm{pH} \mathrm{7.5.} \mathrm{The} \mathrm{pellet} \mathrm{was}$ resuspended in $40 \mathrm{ml}$ of the same buffer and subjected to French Pressing at a constant pressure of 1000 p.s.i. (6.9 MPa). Cell debris was removed by centrifugation at $42000 \mathrm{~g}, 4{ }^{\circ} \mathrm{C}$ for $60 \mathrm{~min}$ in a Sorvall RC5C centrifuge.

Detection of PepA activity. To show expression of PepA in $E$. coli FI7894, crude cell extracts were applied to non-denaturing PAGE gels ( $8 \%, w / v$, acrylamide, $\mathrm{pH} 8.0$ ) according to the method of Davis (1964), and the protein visualized by staining with Coomassie Blue. PepA activity in these gels was localized by a modification of the method of Hermsdorf (1978). The gels were overlaid with $1 \%(\mathrm{w} / \mathrm{v})$ agar containing $130 \mathrm{mM} \mathrm{MnSO}_{4}$, $40 \mathrm{mM}$ EDTA, $50 \mathrm{mM}$ Tris pH 8.0, $2 \mathrm{mM}$ Glu-Trp, $0.1 \mathrm{mg}$ dianisidine $\mathrm{ml}^{-1}, 0.1 \mathrm{mg}$ amino acid oxidase $\mathrm{ml}^{-1}$ and $0.2 \mathrm{mg}$ peroxidase $\mathrm{ml}^{-1}$. Oxidation of dianisidine produces a dark orange zone indicating glutamyl aminopeptidase activity. PepA activity of $p e p A$ mutant strains was determined by the method of Niven (1991): $50 \mu \mathrm{l}$ cell extract was added to $450 \mu \mathrm{l} 0 \cdot 1 \mathrm{M}$ Tris/ $\mathrm{HCl}, \mathrm{pH} 7 \cdot 5$, and $500 \mu \mathrm{l} 2 \mathrm{mM}$ Glu-pNA. This was incubated for $1 \mathrm{~h}$ at $50^{\circ} \mathrm{C}$ and the reaction stopped by the addition of $500 \mu \mathrm{l} 30 \%(\mathrm{v} / \mathrm{v})$ acetic acid. The sample was then centrifuged at $10000 \mathrm{~g}$ for $5 \mathrm{~min}$ and the absorbance determined at $410 \mathrm{~nm}$.

Determination of protein concentration. Protein concentration in cell extracts was determined using the Bio-Rad DC Protein assay according to the manufacturer's instructions, using bovine serum albumin standards.

\section{RESULTS AND DISCUSSION}

\section{Library screening and sub-cloning}

PepA has been purified from $L$. lactis NCDO 712 (Niven, 1991). The sequence of 25 residues at the $\mathrm{N}$-terminus of the purified enzyme was determined by automated gasphase sequencing as: Met-Glu-Leu-Phe-Asp-Lys-ValLys-Ala-Leu-Thr-Glu-Ile-Gln-Ala-Thr-Ser-Gly-Phe-GluGly-Pro-Val-Arg-Asp. This sequence was used to design the degenerate primers subsequently used. PCR amplification of $L$. lactis chromosomal DNA with oligonucleotide primers $1 \mathrm{C}$ and $5 \mathrm{C}$ resulted in production of a 75 bp fragment. The FI5876 lambda ZAP library was screened with these primers (as described in Methods) and positive plaques were identified by the generation of a $75 \mathrm{bp}$ product. Approximately 3000 plaques were screened in this way and four gave a positive result. DNA from one of the four plaques was isolated and a $4 \cdot 2 \mathrm{~kb}$ EcoRI fragment was subcloned into pUC18 to create pFI872, which was then introduced into E. coli MC1022 to generate strain FI7894.

A strong PepA activity was found in the crude extract of E. coli FI7894 when assayed with Glu-pNA (data not (a) A

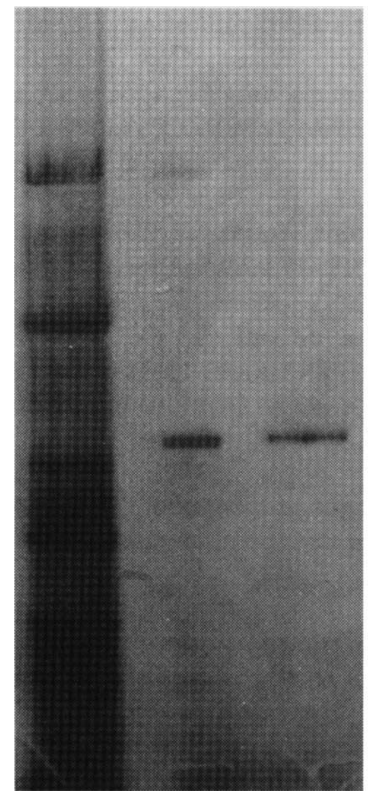

(b)

A B C

Fig. 1. (a) Coomassie Blue staining of non-denaturing PAGE to show expression of PepA in $E$. coli FI7894. Lanes: A, extract from $E$. coli MC1022 (not diluted); B, cell extract from $E$. coli FI7894 (diluted $50 \times$ with $50 \mathrm{mM} \mathrm{Tris/HCl,} \mathrm{pH} \mathrm{7.5);} \mathrm{C,} \mathrm{purified}$ PepA from $L$. lactis MG1363 $(10 \mu \mathrm{g})$. (b) Non-denaturing PAGEzymogram to show activity of PepA in E. coli F17894. Lanes: A, cell extract from $E$. coli FI7894 (diluted $50 \times$ with $50 \mathrm{mM}$ Tris/HCl, $\mathrm{pH} 7 \cdot 5$ ); B, purified PepA from L. lactis MG1363 $(10 \mu \mathrm{g}) ; C$, cell extract from $E$. coli MC1022 (not diluted). The band of PepA activity is arrowed.

shown). The extract from FI7894 was diluted 50-fold in $50 \mathrm{mM}$ Tris/ $\mathrm{HCl}, \mathrm{pH} 7 \cdot 5$, prior to application onto nondenaturing gels and gave a similar level of activity to $10 \mu \mathrm{g}$ purified PepA on the zymogram (stained by dianisidine oxidation). In both the protein-stained gel (Fig. 1a) and the zymogram (Fig. 1b) a band was clearly observed in FI7894 that corresponded to the purified PepA from $L$. lactis and this was not present in the MC1022 extracts. E. coli MC1022 had very little GlupNA-hydrolysing activity and the presence of the nonPepA oxidation bands observed in Fig. 1(b) for E. coli MC1022 extracts probably reflects the use of an undiluted sample. The strong expression of PepA in FI7894 is clearly shown in Fig. 1(a), where it is the major protein present in the 50 -fold diluted crude extract.

\section{Sequencing and analysis of the EcoRI fragment}

Both strands of the $4.2 \mathrm{~kb}$ EcoRI DNA fragment were sequenced (only $2.1 \mathrm{~kb}$ shown here) using a 'walking' sequencing strategy in which synthetic primers were designed from the determined sequence. Analysis of the sequenced region revealed the presence of one complete and two incomplete ORFs (Fig. 2). ORF 1 has an ATG start codon at nucleotide 642 and a stop codon (TAA) at 
1 ttcccataattccccactcgatagcaagatccatgtactcatcacggtctacttcaacaaatctaaattctggattctctgtttcaattt AAGGGTATTAAGGGGTGAGCTATCGTTCTAGGTACATGAGTAGTGCCAGATGAAGTTGTTTAGATTTAAGACCTAAGAGACAAAGTTAAA

$\begin{array}{llllllllllllllllllllllllllllllll}G & M & I & G & W & E & I & A & L & D & M & Y & E & D & R & D & V & E & V & E & R & F & E & P & N & E & T & E & I\end{array}$

91 ctggcattttaggtttgataaaattacaatctccacaccaaccagctgtgaaaaagaagactgttttttctgggcctttgacaagctcag GACCGTAAAATCCAAACTATTTTAATGTTAGAGGTGTGGTTGGTCGACACTTTTTCTTCTGACAAAAAAGACCCGGAAACTGTTCGAGTC $\begin{array}{lllllllllllllllllllllllllllllllll}E & P & M & K & P & K & I & F & N & C & D & G & C & W & G & A & T & F & F & F & V & T & K & E & P & G & K & V & L & E\end{array}$

181 ctaaattttcaatattttctggaataatcattctgtatttcctttcgtatttttcaaatggattctaaccatttctaaagaagttcttc GATTTAAAAGTTATAAAAGACCTTATTAGTAagacataaaggaaagcataaaaagtttacctaagattggtaaaagatttcttcaagaag

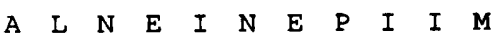

$$
\text { - <--- orf } 3
$$

271 ttttttttcaaaaacttctaaagttttggcattgatttcaaaagcaatagatttatcattactgacaattccccttcaaaaagggcacc

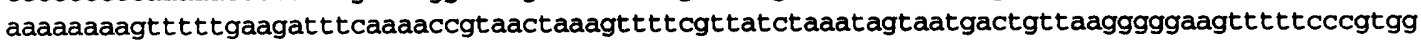

361 agaàgttggctcatcaaaaatccaaaaagcatcaattttttttgtagaaaaatgttgtcggactctatcagtaagctcatgaatcatttc tcttcaaccgagtagtttttaggtttttcgtagttaaaaaaacatctttttacaacagcctgagatagtcattcgagtacttagtaaag

451 ttcttccatgtttttataaccatgataagctgcgtgagcaacggctgctcccgcgacaattcccaaaccaaactttagtatttttttcat aagaaggtacaaaaatattggtactattcgacgcactcgttgccgacgagggcgctgttaagggtttggtttgaaatcataaaaaaagta 16bp spacing_,

541 atggaaattTTAACAtattcttggtataatTATAGTgtaaatcatcaaaagaattactgacagattegtcagtaaatttttcagtatcC tacctttaaaattgtataaagaaccatattaatatcacatttagtagttttcttaatgactgtctaaacagtcatttaaaaagtcatagg

631 CGGAGGagaaaaATGGAACTATTTGACAAAGTAAAAGCACTGACAGAAATTCAAGCCACTTCTGGTTTTGAAGGTCCCGTTCGCGACTAT gcctcctctttttaccttgataaactgtttcattttcgtgactgtctttaagttcggtgaagaccaaaact tccagggcaagcgctgata

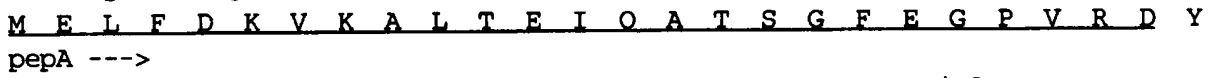

\section{.HindIII .}

721 TTAAAAGCTCGTATGGTTGAGCTAGGCTATCAACCAGAATTTGACGGACTTGGTGGTATTTTTGTGACAAAAGCTTCAAAAGTCGAAAAT aattttcgagcataccaactcgatccgatagttggtcttaaactgcctgaaccaccataaaaacactgttttcgaagttttcagctttta $\begin{array}{lllllllllllllllllllllllllllllll}L & K & A & R & M & V & E & L & G & Y & Q & P & E & F & D & G & L & G & G & I & F & V & T & K & A & S & K & V & E & N\end{array}$

811 GCCCCACGAATCATGGTTGCGGCTCACATGGATGAGGTCGGATTTATGGTCAGCTCAATCAAAGCTGACGGACATTCCGCGTTGTTCCT cggggtgcttagtaccaacgccgagtgtacctactccagcctaaataccagtcgagttagtttcgactgccttgtaaggcgcaacaagga $\begin{array}{lllllllllllllllllllllllllllllllll}\text { A } & P & R & I & M & V & A & A & H & M & D & E & V & G & F & M & V & S & S & I & K & A & D & G & T & F & R & V & V & P\end{array}$

\section{- HincII .}

901 CTTGGTGGTTGGAACCCTTAGTCGTTTCTGGTCAACGTTTTACCCTATTTACACGTACAGGTAAAAAGATTCCGGTTGTAACTGGTGGT gaaccaccaaccttggggaatcagcaaagaccagttgcaaaatgggataaatgtgcatgtccatttttctaaggccaacattgaccacca $\begin{array}{llllllllllllllllllllllllllllllllll}\text { L } & G & G & W & N & P & L & V & V & S & G & Q & R & F & T & L & F & T & R & T & G & K & K & I & P & V & V & T & G & G\end{array}$

ECORV

991 CTTCCTCCACACCTTCTTCGCGGAACTGGTGTAACACCTCAAATCCCACCAATCTCTGATATCATCTTTGATGGTGCATTTGAAAATGCT gaaggaggtgtggaagaagcgccttgaccacattgtggagtttagggtcgttagagactatagtagaaactaccacgtaaacttttacga

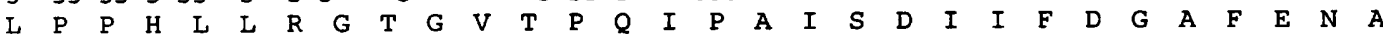

1081 GCCGAAGCTGCCGAATTTGGAATCGCCCAAGGTGATTTAATTATTCCAGAAACAGAAACAATTCTGTCAGCAAATGGGAAAATATCATT cggcttcgacggct taaacct tagcgggttccactaaattaataaggtctttgtctttgttaagacagtcgtttaccctttttatagtaa

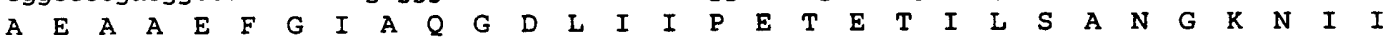

HindIII

1171 TCTAAAGCTIGGGATAATCGCTATGGTTGCTTAATGATTCTTGAACTTCTTGAATTTTTAGCTGACAAAGAATTACCTGTAACATTAATT agatttcgaaccctattagcgataccaacgaattactaagaacttgaagaacttaaaaatcgactgtttcttaatggacattgtaattaa $\begin{array}{lllllllllllllllllllllllllllllll}S & K & A & \text { W } & D & \text { N } & \text { R } & \text { Y } & G & \text { C } & \text { L } & \text { M } & \text { I } & \text { L } & \text { E } & \text { L } & \text { L } & \text { E } & \text { F } & \text { L } & \text { A } & \text { D } & \text { K } & \text { E } & \text { L } & \text { P } & \text { V } & \text { T } & \text { L } & \text { I }\end{array}$

1261 ATTGGAGCGAATGTTCAAGAGGAAGTCGGACTTCGTGGTGCAAAAGTTTCCACAACCAAATTCAATCCTGATTTATTCTTTGCCGTTGAC taacctcgcttacaagttctccttcagcctgaagcaccacgttttcaaaggtgttggtttaagttaggactaaataagaaacggcaactg $\begin{array}{llllllllllllllllllllllllllllllll}I & G & A & N & V & Q & E & E & V & G & L & R & G & A & K & V & S & T & T & K & F & N & P & D & L & F & F & A & V & D\end{array}$

Fig. 2. For legend see facing page. 
1351 TGTTCACCAGCAAGCGATACCTTCGGTGACGATAATGGTCGCCTCGGAGAAGGAACAACGCTCCGTTTCTTCGACCCAGGTCATATCATG acaagtggtcgttcgctatggaagccactgctattaccagcggagcctcttccttgttgcgaggcaaagaagctgggtccagtatagtac $\begin{array}{lllllllllllllllllllllllllllllll}C & S & P & A & S & D & T & F & G & D & D & N & G & R & L & G & E & G & T & T & L & R & F & F & D & P & G & H & I & M\end{array}$

1441 CTTCCTGGAATGAAGAACTTCTTACTTGACACTGCAAATCATGCCAAAGTTAAAACACAAGTTTACATGGCCAAAGGGGAACCGATGCA gaaggacct tacttcttgaagaatgaactgtgacgtttagtacggtttcaattttgtgttcaaatgtaccggtttcccccttggctacgt $\begin{array}{llllllllllllllllllllllllllllllll}\text { L } & P & G & M & K & N & F & \text { L } & \text { L } & D & \text { T } & A & \text { N } & \text { H } & \text { A } & K & \text { V } & K & T & Q & V & Y & M & A & K & G & G & T & D & A\end{array}$

1531 GGTGCCGCTCATTTAGCAAATGGAGGAGTTCCTTCAACAACAATCGTTGGGTAGCCCGCTATATCCATAGCCATCAAACTATTTTCAAC ccacggcgagtaaatcgtt tacctcctcaaggaagttgttgttagccacaccatcgggcgatataggtatcggtagtttgataaaagttg $\begin{array}{llllllllllllllllllllllllllllllll}G & A & A & H & L & A & N & G & G & V & P & S & T & T & I & G & V & V & A & R & Y & I & H & S & H & Q & T & I & F & N\end{array}$

1621 ATTGATGATTTTCTTCAAGCTCAAACTTTCTTGAGAGCGATTATTACTTCACTTAATACTGAAAAAGTAGCAGAAATCAAAAACTACTAA taactactaaaagaagt tcgagtttgaaagaactctcgctaataatgaagtgaattatgactttttcatcgtctttagtttttgatgatt $\begin{array}{llllllllllllllllllllllllllllllll}I & D & D & F & L & Q & A & Q & T & F & L & R & A & I & I & T & S & L & N & T & E & K & V & A & E & I & K & N & Y & *\end{array}$

1711 ttctaataaaaaaacactaggaatttatcctagtgtttttttagttactttttgatgaggaagtctgactaaaattgaaagaaggtaaaa aagattatttttttgtgatcct taaataggatcacaaaaaAATCAATGAAAAACTACTCCTTCAGACTGATTTTAACTTTCTTCCATTTT * $N$ N $S$ S

1801 ttttcttccaaccagcagctatatcactagctgacccacctatagagaaatcataggtagtagtaggtgctcctgctttagtagcccaga AAAAGAAGGTTGGTCGTCGATATAGTGATCGACTGGGTGGATATCTCTTTAGTATCCATCATCATCCACGAGGACGAAATCATCGGGTCT $\begin{array}{llllllllllllllllllllllllllllllll}I & K & K & W & G & A & A & I & D & S & A & S & G & G & I & S & F & D & Y & T & T & T & P & A & G & A & K & T & A & W\end{array}$ HincII

1891 agctagtcgttgtttctccgccaaggttgacttcttgagtcttaccatttgctagtttaactgtgactttccctggtttttctcctgtag TCGATCAGCAACAAAGAGGCGGTTCCAACTGAAGAACTCAGAATGGTAAACGATCAAATTGACACTGAAAGGGACCAAAAAGAGGACATC $\begin{array}{lllllllllllllllllllllllllllllllll}F & S & T & T & T & E & G & G & L & N & V & E & Q & T & K & G & N & A & L & K & V & T & V & K & G & P & K & E & G & T\end{array}$

1981 aaaccaatactttacttttagtaacatttggatcagtatttggatcagtaaatttttgtccagggccaaaaatgtttggatcagctgcat TTTGGTTATGAAATGAAAATCATTGTAAACCTAGTCATAAACCTAGTCATTTAAAAACAGGTCCCGGTTTTTACAAACCTAGTCGACGTA $\begin{array}{llllllllllllllllllllllllllllllllllll}S & V & L & V & K & S & K & T & V & N & P & D & T & N & P & D & T & F & K & Q & G & P & G & F & I & N & P & D & A & A\end{array}$

2071 taatcgcattaaccaattgtgcaatataag 2100 ATTAGCGTAATTGGTTAACACGTTATATTC N $\quad I \begin{array}{lllllllllllll} & \text { A } & \text { V } & \text { L } & Q & A & \text { I } & Y\end{array}$

$$
<-- \text { orf } 2
$$

\begin{abstract}
Fig. 2. Nucleotide sequence of $2 \cdot 1 \mathrm{~kb}$ of the lactococcal insert of pFl872. The upper strand contains the coding sequence of pepA (nt 643-1710) and the lower strand those of two incomplete ORFs. The deduced amino acid sequences are given below the nucleotide sequence. Six base pairs upstream of the putative pepA ATG start codon is a putative ribosomebinding site GGAGG (underlined); sequences that resemble promoter - 10 and -35 elements (van de Guchte et al., 1992) are underlined and in upper-case letters. An inverted repeat stretching from nt 1717 to nt 1753 with a $\Delta G$ value of $-21.4 \mathrm{kcal} \mathrm{mol}^{-1}\left(-89.5 \mathrm{~kJ} \mathrm{~mol}^{-1}\right)$ may act as a transcription terminator for both pepA and ORF2. A number of relevant restriction sites are indicated. The $\mathrm{N}$-terminal 25 amino acids of PepA (whose sequence was also determined experimentally) are also underlined.
\end{abstract}

nt 1710 , giving it a total length of $1065 \mathrm{bp}$. It has the potential to specify a protein of $38.1 \mathrm{kDa}$. The $\mathrm{N}$-terminal 25 amino acids of the translated sequence of ORF 1 were identical to those determined experimentally from purified PepA (underlined in Fig. 2). There was a potential Shine-Dalgarno sequence (Shine \& Dalgarno, 1974) at nt 632-636 and putative lactococcal promoter sequences (van de Guchte et al., 1992) at nt 572-577 and 550-555. The incomplete ORF downstream of pep $A$ (ORF 2) has a TAA stop codon at $\mathrm{nt} 1753$. The region between these two ORFs from nucleotides 1717 to 1753 has the potential to form a stem-loop of $16 \mathrm{bp}$ (containing four $\mathrm{G}^{\cdot} \mathrm{C}$ pairs and no mismatches). It is possible that this could act as a bidirectional transcription terminator for both ORFs. There was also a third, incomplete ORF (ORF 3) upstream of $\operatorname{pep} A$ with an ATG start codon at nt 211. Analysis of all three putative ORFs (using the program CODONPREFERENCE) with lactococcal codon usage tables (van de Guchte, 1991), predicted that these ORFs are likely to be efficiently expressed in $L$. lactis.

The purified PepA that provided the $\mathrm{N}$-terminal sequence data presented in this paper was isolated from an intracellular extract (Niven, 1991). However, the initial characterization of the enzyme (Exterkate \& de Veer, $1987)$ indicated that it was a membrane-bound enzyme. 


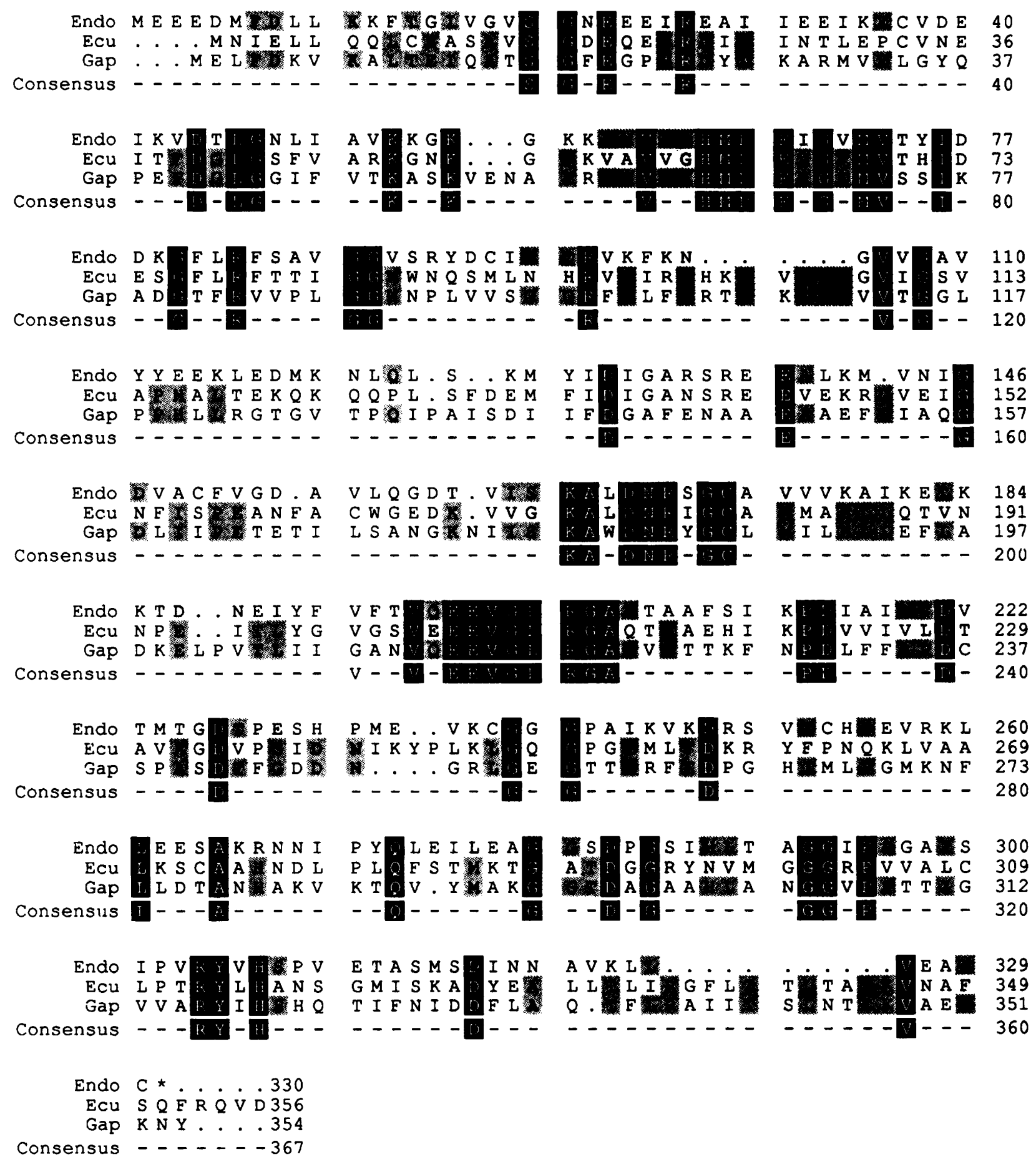

Fig. 3. Comparison of the deduced PepA amino acid sequence (Gap [glutamyl aminopeptidase]) with that of an endoglucanase from Clostridium thermocellum (Endo) and the translation of an ORF from the $E$. coli chromosome from 87.2 to $89.2 \mathrm{~min}$ (Ecu). Identical amino acids in all three of the aligned sequences are boxed in black and those identical to PepA in either one or the other sequences in dark grey. Spaces indicated by dots were introduced in order to obtain maximum alignment.

More recent immunohistochemical localization studies (Baankreis, 1992) also suggested a peripheral/ extracellular location for PepA, although cellular fractionation experiments in the same study showed that PepA activity was largely associated with the cytosolic fraction, with some activity (higher than found with other intracellular peptidases) associated with the solubilized cell wall fraction. The $p e p A$ gene sequence has no recognized $\mathrm{N}$-terminal signal sequences, and hydrophobicity plots (Kyte \& Doolittle, 1982) of the PepA 
(a)

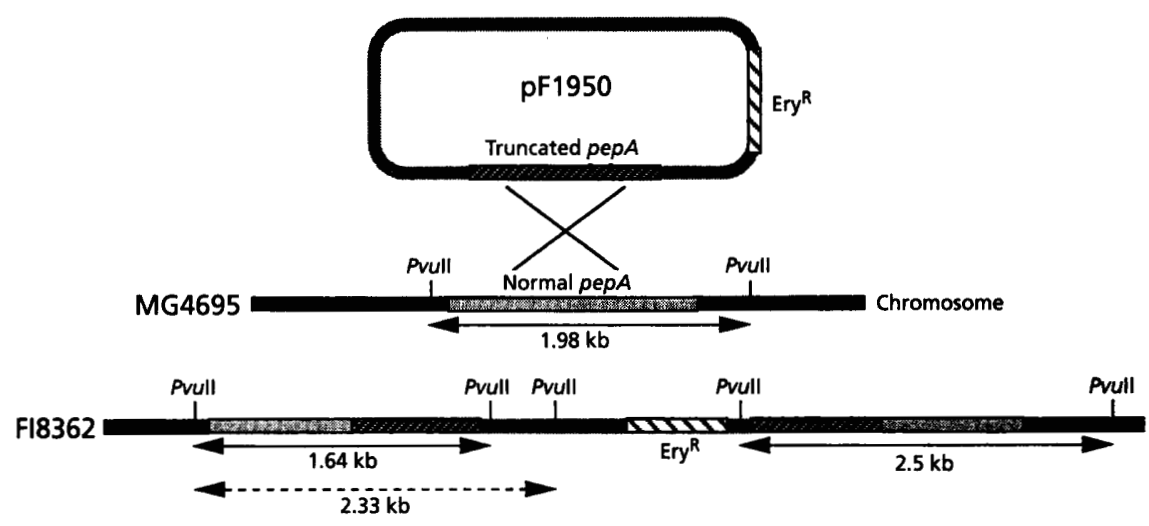

(b)

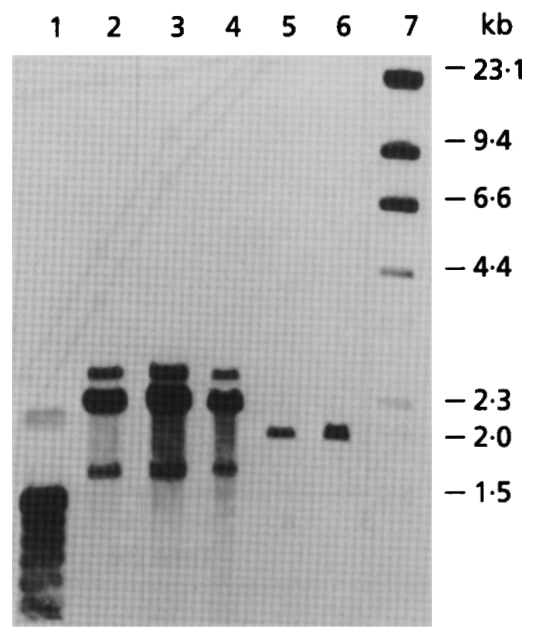

Fig. 4. (a) Schematic representation of Campbell-like integration of pFI950 into the chromosomal pepA gene in $L$. lactis MG4695 and (b) Southern hybridization of chromosomal DNA from the parental strain MG4695 and the integrant(s) F18362, Fl8364 and Fl8365 digested with Pvull. The truncated pepA from pFI950 was used as a probe. The sizes of the expected hybridizing restriction fragments are indicated in (a). Lanes: 1, 100 bp ladder; 2, F18362 digested with Pvull; 3, Fl8364 digested with Pvull; 4, F18365 digested with Pvull; 5, MG1363 digested with Pvull; 6, MG4695 digested with Pvull; 7, phage lambda DNA digested with Hindill.

protein (not shown) indicated no potential hydrophobic transmembrane domains. These findings suggest that PepA is an intracellular peptidase. This conclusion is supported by a recent study which showed that the lactococcal extracellular cell wall proteinase can, from a growth medium where $\beta$-casein (supplemented with the leucine and histidine) is the only nitrogen source, provide sufficient transportable peptides to support maximal growth, no extracellular peptidases being required (Kunji et al., 1995). Indeed all lactococcal peptidases that have been isolated thus far are intracellular, leading to the conclusion that $L$. lactis does not require any extracellular peptidases (Pritchard \& Coolbear, 1993).

\section{Homology comparisons}

The predicted amino acid sequence from ORF 1 ( $p e p A)$ was compared to the translated DNA sequences in the EMBL database using the program TFASTA (Pearson \& Lipman, 1988). The analysis showed that the $p e p A$ gene product (PepA) has $30.3 \%$ identity, in a 294 amino acid overlap, with an endoglucanase from Clostridium thermocellum (Romaniec et al., 1992). It also has $32.8 \%$ identity, in a 357 amino acid overlap, with the gene product from a region of the $E$. coli chromosome from 87.2 to $89.2 \mathrm{~min}$ which specifies an ORF of unknown function (Plunkett $e t$ al., 1993) (Fig. 3).

\section{Construction of PepA-deficient lactococcal strains}

To investigate whether PepA is essential for the growth of $L$. lactis in milk, the $p e p A$ gene was inactivated. The suicide vector pFI950 is based on the plasmid pCRII (see Methods). It has an internal, truncated region of the $p e p A$ gene $(0.76 \mathrm{~kb}$, generated by PCR) which lacks both the first 136 bases and the last 111 bases of $p e p A$ cloned into the EcoRI site of pCRII. In addition to this, an erythromycin resistance gene was cloned into the Bam HI site in the multiple cloning site of pCRII. Insertional inactivation of $p e p A$ was achieved by transformation of L. lactis MG4695 (a derivative of MG1363 carrying the $\mathrm{Lac}^{+} \mathrm{Prt}^{+}$plasmid pLP712: Gasson, 1983) with pFI950. This plasmid has no Gram-positive origin of replication and selection for erythromycin-resistant transformants facilitated integration of pFI950 into the $p e p A$ gene in the chromosome of MG4695 by Campbell-like single crossover recombination. This resulted in the presence of two incomplete copies of the $p e p A$ gene, one lacking the first 136 bases and the other lacking the last 111 bases (Fig. 4a).

Erythromycin-resistant colonies were analysed by Southern hybridization for integration of $\mathrm{pFI} 950$ and interruption of the $p e p A$ gene. $\mathrm{A} p e p A$ probe was hybridized with PvuII-digested chromosomal DNA from erythromycin-resistant colonies. Strains containing the integrated plasmid were predicted to contain two fragments $(1.64 \mathrm{~kb}$ and $2.5 \mathrm{~kb})$ which would hybridize with the probe; wild-type strains would have only one band $(1.98 \mathrm{~kb})$ capable of hybridization. Strains FI8362, FI8364 and FI8365 contained the two hybridizing fragments that were expected, indicating that integration of pFI950 into $p e p A$ had indeed occurred in these strains (Fig. 4b).

Cell extracts were prepared from the isolated clones and assayed for PepA activity. The three strains (FI8362, FI8364 and FI8365) were all deficient in PepA activity (data not shown). Their ability to grow in milk was examined. The PepA deficiency in all three mutants isolated resulted in a delay in the onset of the exponential 

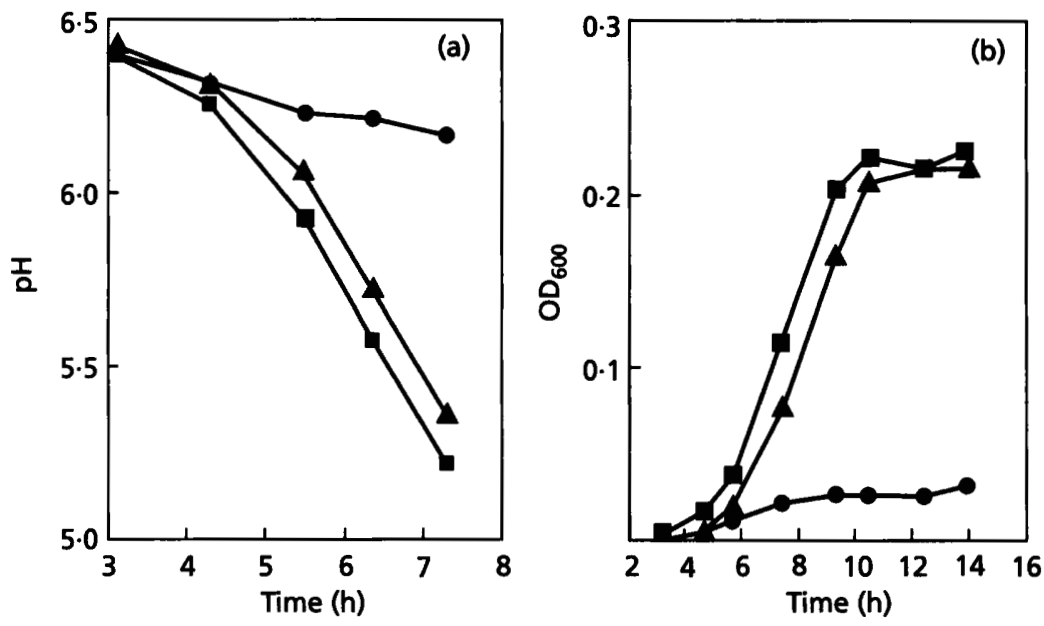

Fig. 5. Growth of the pepA mutant F/8362 in milk, as shown by acidification rates (a) and by $O D_{600}$ measurements (b). $A$, Mutant Fl8362 (proteinase positive, PepA negative); - MG1363 (proteinase negative, PepA positive); $\square$, MG4695 (proteinase positive, PepA positive).

phase of growth (shown for FI8362 in Fig. 5). Although the delay was only slight it was reproducible across three separate cultures; each time point was the mean of three readings from each culture. At $3.5 \mathrm{~h}$ there was no significant difference but between 4 and $9 \mathrm{~h}$ the difference was significant at the $99 \%$ confidence level. At $10.5 \mathrm{~h}$ this dropped to $95 \%$ confidence, and then the difference became insignificant. Thus the difference is highly significant throughout the exponential phase and probably arises from a longer lag phase in the mutant strains. Variation in the lag phase as a consequence of environmental history is an established concept in microbial growth modelling (Baranyi et al., 1995) and it is conceivable that loss of a peptidase has a similar effect. As has been found with other peptidases reported thus far (Mierau et al., 1993a), PepA was also not an essential peptidase for ultimate growth of $L$. lactis in milk. This is, perhaps, not unexpected as lactococci contain at least three other intracellular peptidases, namely a dipeptidase (Hwang et al., 1981), a tripeptidase (Bosman et al., 1990) and PepC (Neviani et al., 1989), that are reported to hydrolyse glutamate-containing peptides or chromogenic substrates. Therefore, it may be anticipated that these enzymes would be able to substitute for PepA in the deficient strains, although the efficiency may be reduced, resulting in the delay in early growth. As the transport of free glutamate is $\mathrm{pH}$ dependent in lactococci, with increased translocation as acidification occurs (Poolman et al., 1987), it is likely that greater emphasis may be placed on peptides, either from the non-protein nitrogen or as the result of proteolysis of milk proteins, supplying essential glutamate at the higher $\mathrm{pH}$ found in the early growth phase, for which the glutamyl-cleaving peptidases would then be required. It may, therefore, be anticipated that any effect of a $p e p A$ deletion supplying essential glutamate would be more prominent in the early phase of growth.

\section{ACKNOWLEDGEMENTS}

This work was supported by contract BIOT-CT91-0263 from the BRIDGE programme of the Commission of the European Community.

\section{REFERENCES}

van Alen-Boerrigter, I. J., Baankreis, R. \& de Vos, W. M. (1991). Characterization and over expression of the Lactococcus lactis pepN gene and localization of its product, aminopeptidase N. Appl Environ Microbiol 57, 2555-2561.

Baankreis, R. (1992). The role of lactococcal peptidases in cheese ripening. $\mathrm{PhD}$ thesis, University of Amsterdam.

Baranyi, J., Robinson, T. P., Shukla, A. \& Mackey, B. M. (1995). Predicting growth of Brochotbrix thermosphacta at changing temperature. Int $J$ Food Microbiol (in press).

Bosman, B. W., Tan, P. S. T. \& Konings, W. N. (1990). Purification and characterisation of a tripeptidase from Lactococcus lactis subsp. cremoris Wg2. Appl Environ Microbiol 56, 1839-1843.

Casadaban, M. J. \& Cohen, S. N. (1980). Analysis of gene control signals by DNA fusion and cloning in E. coli. J Mol Biol 138, 179-207.

Chapot-Chartier, M.-P., Nardi, M., Chopin, M.-C., Chopin, A. \& Gripon, J.-C. (1993). Cloning and sequencing of $p e p C$, a cysteine aminopeptidase gene from Lactococcus lactis subsp. cremoris AM2. Appl Environ Microbiol 59, 330-333.

Davis, B. J. (1964). Disc electrophoresis II. Ann NY Acad Sci 121, 404-427.

Dodd, H. M., Horn, N. \& Gasson, M. J. (1990). Analysis of the genetic determinant for production of the peptide antibiotic nisin. $J$ Gen Microbiol 136, 555-566.

Exterkate, F. A. \& de Veer, G. J. C. M. (1987). Purification and some properties of a membrane bound aminopeptidase A from Streptococcus cremoris. Appl Environ Microbiol 53, 577-583.

Gasson, M. J. (1983). Plasmid complements of Streptococcus lactis NCDO 712 and other lactic streptococci after protoplast induced curing. J Bacteriol 154, 1-9.

Gooderham, K. (1984). Transfer techniques in protein blotting. Metbods Mol Biol 1, 165-178.

Griffin, H. G., I'Anson, K. J. A. \& Gasson, M. J. (1993). Rapid isolation of genes from bacterial lambda libraries by direct polymerase chain reaction screening. FEMS Microbiol Lett 112, 49-54.

van de Guchte, M. (1991). Heterologous gene expression in L. lactis. $\mathrm{PhD}$ thesis, University of Groningen.

van de Guchte, M., Kok, J. \& Venema, G. (1992). Gene expression in Lactococcus lactis. FEMS Microbiol Rev 88, 73-92.

Gussow, D. \& Clackson, T. (1989). Direct clone characterisation 
from plaques and colonies by the polymerase chain reaction. Nucleic Acids Res 17, 4000.

Hagting, A., Kunji, E. R. S., Leenhouts, K. J., Poolman, B. \& Konings, W. N. (1994). The di- and tripeptide transport protein of Lactococcus lactis. J Biol Chem 269, 11391-11399.

Hermsdorf, C. L. (1978). Rapid assay to detect peptidases in column effluent fractions using L-amino acid oxidase. Anal Biochem 90, 835-839.

Holo, H. \& Nes, I. F. (1989). High-frequency transformation, by electroporation, of Lactococcus lactis subsp. cremoris grown with glycine in osmotically stabilized media. Appl Environ Microbiol 55, 3119-3123.

Hunkapillar, M. W., Hewick, R. E., Dreyer, W. J. \& Hood, L. E. (1983). High sensitivity sequencing with a gas phase sequencer. Methods Enyymol 91, 399-413.

Hwang, I.-K., Kaminogawa, S. and Yamauchi, K. (1981). Purification and properties of a dipeptidase from Streptococcus cremoris. Agric Biol Chem 45, 159-165.

Kanasaki, M., Breheny, S., Hillier, A. J. \& Jago, G. R. (1975). Effect of temperature on the growth and acid production of lactic acid bacteria. I. A rapid method for the estimation of bacterial populations in milk. Aust J Dairy Tecbnol 30, 142-144.

Kok, J. (1990). Genetics of the proteolytic system of lactic acid bacteria. FEMS Microbiol Rev 87, 15-42.

Kunji, E. R. S., Hagting, A., De Vries, C. J., Juillard, V., Haandrikman, A. J., Poolman, B. \& Konings, W. N. (1995). Transport of $\beta$-casein-derived peptides by the oligopeptide transport system is a crucial step in the proteolytic pathway of Lactococcus lactis. J Biol Chem 270, 1569-1574.

Kyte, J. \& Doolittle, R. F. (1982). A simple method for displaying the hydropathic character of a protein. J Mol Biol 157, 105-132.

Laan, H., Smid, E. J., Tan, P. S. T. \& Konings, W. M. (1989). Enzymes involved in the degradation and utilization of casein in Lactococcus lactis. Neth Milk Dairy J 43, 327-345.

Law, B. A. (1987). Proteolysis in relation to normal and accelerated cheese ripening. Cheese: Chemistry, Physics and Microbiology, vol. 1, General Aspects, pp. 365-392. Edited by P. F. Fox. Amsterdam: Elsevier.

Lewington, J., Greenaway, S. D. \& Spillane, B. J. (1987). Rapid small scale preparation of bacteria genomic DNA, suitable for cloning and hybridisation analysis. Lett Appl Microbiol 5, 51-53.

Marck, C. (1988). 'DNA Strider': a ' $C$ ' program for the fast analysis of DNA and protein sequences on the Apple Macintosh family of computers. Nucleic Acids Res 16, 1829-1836.

Mayo, B., Kok, J., Venema, K., Bockelman, W., Teuber, M., Reinke, H. \& Venema, G. (1991). Molecular cloning and sequence analysis of the $\mathrm{X}$-prolyl dipeptidyl aminopeptidase gene from Lactococcus lactis subsp. cremoris. Appl Environ Microbiol 57, 38-44.

Mierau, I., Haandrikman, A. J., Leenhouts, K. J., Kok, J. and Venema, G. (1993a). Analysis of lactococcal strains mutated in peptidase genes. FEMS Microbiol Rev 12, 83.

Mierau, I., Tan, P. S. T., Haandrikman, A. J., Kok, J., Leenhouts, K. J., Konings, W. N. \& Venema, G. (1993b). Cloning and sequencing of the gene for a lactococcal endopeptidase, an enzyme with sequence similarity to mammalian enkephalinase. $J$ Bacteriol 175, 2087-2096.

Mierau, I., Haandrikman, A. J., Velterop, O., Tan, P. S. T., Leenhouts, K. L., Konings, W. N., Venema, G. \& Kok, J. (1994). Tripeptidase gene $(p e p T)$ of Lactococcus lactis: molecular cloning and nucleotide sequencing of $p e p T$ and construction of a chromosomal deletion mutant. $J$ Bacteriol 176, 2854-2861.

Mills, O. E. \& Thomas, T. D. (1981). Nitrogen sources for growth of lactic streptococci in milk. N Z J Dairy Sci Technol 15, 43-45.

Monnet, V., Nardi, M., Chopin, A., Chopin, M.-C. \& Gripon, J.-C. (1994). Biochemical and genetic characterisation of PepF, an oligopeptidase from Lactococcus lactis. J Biol Chem 269, 32070-32076.

Neviani, E., Boquien, C. Y., Monnet, V., Phan Than, L. \& Gripon, J.-C. (1989). Purification and characterisation of an aminopeptidase from Lactococcus lactis subsp. cremoris AM2. Appl Environ Microbiol 55, 2308-2314.

Niven, G. W. (1991). Purification and characterisation of aminopeptidase A from Lactococcus lactis subsp. lactis NCDO 712. J Gen Microbiol 137, 1207-1212.

Pearson, W. R. \& Lipman, D. J. (1988). Improved tools for biological sequence comparison. Proc Natl Acad Sci USA 85, 2444-2448.

Plunkett, G., III, Burland, V., Daniels, L. D. \& Blattner, F. R. (1993). Analysis of the Escberichia coli genome. III. DNA sequence of the region from 87.2 to 89.2 minutes. Nucleic Acids Res 21, 3391-3398.

Poolman, B. (1993). Energy transduction in lactic acid bacteria. FEMS Microbiol Rev 12, 125-147.

Poolman, B., Smid, E. J. \& Konings, W. N. (1987). Kinetic properties of a phosphate-bond-driven glutamate-glutamine transport system in Streptococcus lactis and Streptococcus cremoris. J Bacteriol 69, 2755-2761.

Pritchard, G. G. \& Coolbear, T. (1993). The physiology and biochemistry of the proteolytic system in lactic acid bacteria. FEMS Microbiol Rev 12, 179-206.

Puchades, R., Lemieux, L. \& Simard, R. E. (1989). Evolution of free amino acids during the ripening of Cheddar cheese containing added lactobacilli strains. $J$ Food Sci 54, 885-888.

Romaniec, M. P. M., Fauth, U., Kobayashi, T., Huskisson, N. S., Barker, P. J. \& Demain, A. L. (1992). Purification and characterization of a new endoglucanase from Clostridium thermocellum. Biocbem J 283, 69-73.

Sambrook, J., Fritsch, E. F. \& Maniatis, T. (1989). Molecular Cloning: a Laboratory Manual, 2nd edn. Cold Spring Harbor, NY: Cold Spring Harbor Laboratory.

Shine, J. \& Dalgarno, L. (1974). The $3^{\prime}$ terminal sequence of Escherichia coli $16 \mathrm{~S}$ ribosomal RNA: complementarity to nonsense triplets and ribosome binding sites. Proc Natl Acad Sci US A 71, 1342-1346.

Strøman, P. (1992). Sequence of a gene (lap) encoding a $95.3 \mathrm{kDa}$ aminopeptidase from Lactococcus lactis ssp. cremoris WG2. Gene 113, 107-112.

Terzaghi, P. E. \& Sandine, W. E. (1975). Improved medium for lactic streptococci and their bacteriophages. Appl Environ Microbiol 29, 807-813.

Thomas, T. D. \& Mills, O. E. (1981). Proteolytic enzymes of starter bacteria. Neth Milk Dairy J 35, 255-273.

Visser, S. (1993). Proteolytic enzymes and their relationship to cheese ripening and flavour - an overview. J Dairy Sci 76, 329-350.

Yanisch-Perron, C., Vieira, J. \& Messing, J. (1985). Improved M13 phage cloning vectors and host strains: nucleotide sequence of the M13mp18 and pUC19 vectors. Gene 33, 103-119.

Received 20 June 1995; accepted 10 July 1995. 